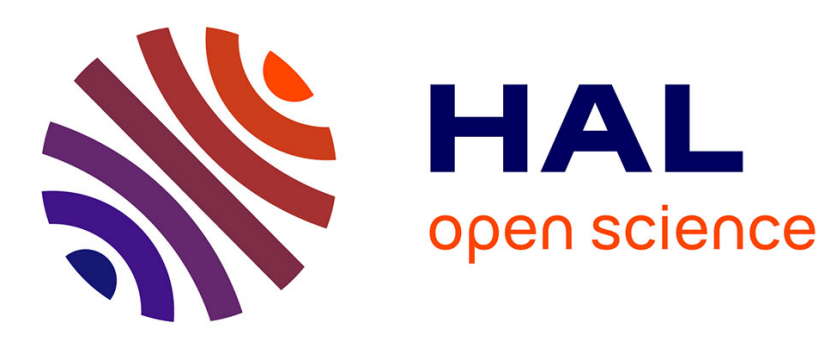

\title{
Todoidal transducer with two large focal zones for increasing the coagulated volume
}

Jeremy Vincenot, David Melodelima, Alexandre Vignot, Francoise Chavrier, Jean-Yves Chapelon

\section{To cite this version:}

Jeremy Vincenot, David Melodelima, Alexandre Vignot, Francoise Chavrier, Jean-Yves Chapelon. Todoidal transducer with two large focal zones for increasing the coagulated volume. Acoustics 2012, Apr 2012, Nantes, France. hal-00810839

\section{HAL Id: hal-00810839 \\ https://hal.science/hal-00810839}

Submitted on 23 Apr 2012

HAL is a multi-disciplinary open access archive for the deposit and dissemination of scientific research documents, whether they are published or not. The documents may come from teaching and research institutions in France or abroad, or from public or private research centers.
L'archive ouverte pluridisciplinaire HAL, est destinée au dépôt et à la diffusion de documents scientifiques de niveau recherche, publiés ou non, émanant des établissements d'enseignement et de recherche français ou étrangers, des laboratoires publics ou privés. 


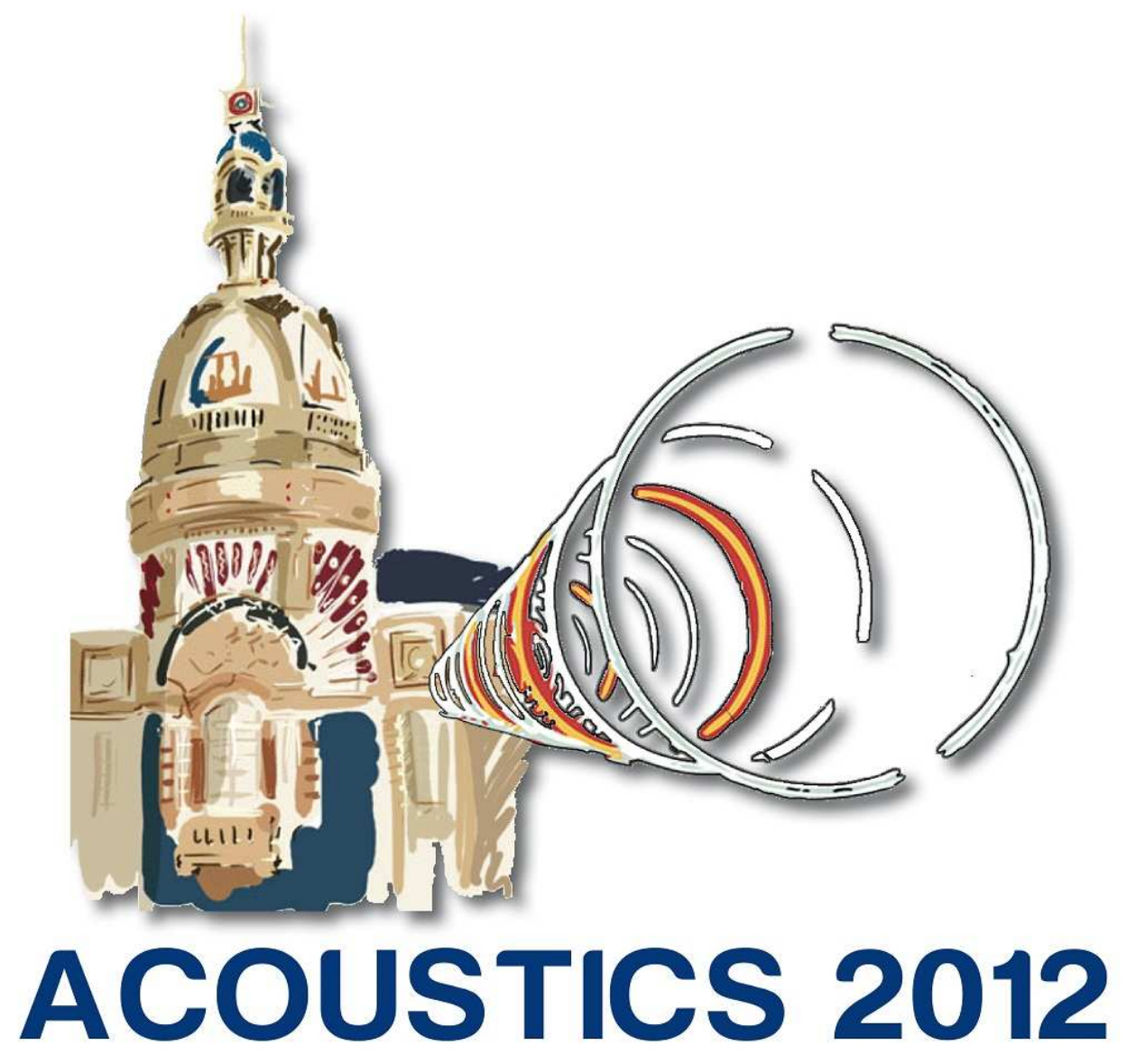

\section{Todoidal transducer with two large focal zones for increasing the coagulated volume}

J. Vincenot ${ }^{\mathrm{a}}$, D. Melodelima ${ }^{\mathrm{a}}$, A. Vignot ${ }^{\mathrm{a}}$, F. Chavrier ${ }^{\mathrm{b}}$ and J.-Y. Chapelon ${ }^{\mathrm{b}}$

${ }^{a}$ Inserm U1032, 151, cours Albert Thomas, 69424 Lyon, France

${ }^{b}$ LabTAU, INSERM, 151 Cours Albert Thomas, 69424 Lyon, France jeremy.vincenot@inserm.fr 